\title{
INVESTIGATION OF WASTE HEAT ENERGY IN A MARINE ENGINE WITH TRANSCRITICAL ORGANIC RANKINE CYCLE
}

\author{
Ibrahim KAYA ${ }^{1, *}$, A. Sinan KARAKURT ${ }^{1}$, Yasin UST $^{1}$
}

\begin{abstract}
The increasing of fuel prices and global energy demand and enactment of new restrictive emissions regulations require more efficient and environmentally friendly engines to be designed. In this context, conversion of waste heat to useful energy is necessary to design more energy efficient vessel including using more efficient main engines and auxiliary engines. The aim of this study, thermodynamic characteristic of recovery of a ship's main engine waste heat is determined parametrically for waste heat recovery system (WHRS). Naturally, heat exchangers are used for waste heat recovery. Because of that reason, firstly shell-and-tube heat exchanger will be investigated parametrically. In order to make a more accurate calculation, it is important to reflect the pressure and enthalpy variations in the heat exchanger to the heat transfer calculations. After that the Transcritical Organic Rankine Cycle (TORC), which is recommended by many authors for the recovery of waste heat sources at low and medium temperatures, will be examined parametrically. The results show that increasing the number of pipes in the heat exchanger at a certain value may result in a decrease in system performance parameters that is The Net Power and Thermal Efficiency due to decreasing velocity of the mass flow in tubes. Moreover, The Net Power and Thermal Efficiency curves behaved differently with variable mass flow rate. Therefore, we will define performance parameter being important for WHRS.
\end{abstract}

Keywords: Waste Heat Recovery, Transcritical Organic Rankine Cycle, Energy

\section{INTRODUCTION}

The increasing of fuel prices and global energy demand and enactment of new restrictive emissions regulations require more efficient and environmentally friendly engines to be designed. In this context, conversion of waste heat to useful energy is necessary to design more energy efficient vessel including using more efficient main engines and auxiliary engines. The huge amount, nearly more than $60 \%$, of fuel energy is rejected from the main diesel engine to the surroundings as waste heat in several types. The main waste heat sources at marine vessel are the main engine exhaust gas, the main engine cooling water and the main engine scavenge air. The exhaust gas with higher energy capacity will be considered as waste heat for analyses. Different kind of technologies exist such as Subcritical and Transcritical Organic Rankine Cycles that are suitable to convert the waste heat to useful power. The transcritical organic Rankine cycles are used more than subcritical systems due to their lower loses and higher performance. In this context, first and second law analyses for diesel engine exhaust gases waste heat used organic Rankine cycle have been done as [1-18]. Economic analysis of organic Rankine cycle (ORC) application for marine diesel engine waste heat recovery system have been carried out in [19-24]. Zabek et al. [25] studied to optimize the conversion of low temperature waste heat to the power by using organic Rankine cycle at oil production system. Landelle et al [26], Kosmadakis et al. [27], Desideri et al. [28] and Hsieh et al. [29] have presented experimental studies to compare the effects of various cycle configurations and different working conditions on the performance of low-temperature subcritical and Transcritical Organic Rankine Cycles. Oyewunmi et al. [30] made an assessment of subcritical and Transcritical Organic Rankine Cycles for waste-heat recovery. Tian et al. [31] investigated the effects of the thermophysical property changes and working conditions at the pseudocritical region on the ORC performance. Zhu et al. [32] have calculated The Net Power output, efficiencies and design parameters in both transcritical and subcritical ORC systems. Dong et al. [33] made an experimental investigation on heat transfer characteristics of widely used the brazing plate type heat exchangers in the organic Rankine cycle waste heat recovery system with using three different working fluids. Wang et al. [34] made an experimentally study for the frictional pressure drop during steam stratified condensation flow in This paper was recommended for publication in revised form by Regional Editor Mustafa KILIC

${ }^{1}$ Department of Naval Architecture and Marine Engineering, Yildiz Technical University, Istanbul, TURKEY

${ }^{*}$ E-mail address: ibrkaya@yildiz.edu.tr

Orcid id: 0000-0003-2593-2472, 0000-0002-6205-9089, 0000-0002-4023-3226

Manuscript Received 12 March 2018, Accepted 02 June 2018 
vacuum horizontal tube. Karellas et al. [35] investigated the influence of supercritical ORC parameters on plate heat exchanger design and defined the basic design parameters for heat exchangers. In this study, $\epsilon$-NTU method was used for heat transfer calculations and also pressure lost at evaporator are taken into consideration. In this study, R1234yf, widely used in ORC, was accepted as working fluid to convert waste heat to the work due to its thermophysical properties, its very low global warming potential and its zero ozone depletion potential [36] and Wartsila 4L20 type marine diesel engine which is fully compliant with the IMO Tier II exhaust emissions regulations, data were used for calculation of the waste heat capacity [37]. The effects of pressure lost and specific enthalpy variations on thermodynamic and transport properties of working fluids are examined parametrically. Beside this, the effects of flow rates of working fluid and main engine exhaust gas, isentropic efficiencies of pump and turbine and the number and the length of heat pipes on The Thermal Efficiency and power generation of waste heat used transcritical organic Rankine cycle are investigated.

\section{SYSTEM MODELING}

\section{System Description}

The TORC system consists of 4 components, as shown in Fig. 1. A shell-and-tube heat exchanger is used to recover the waste heat from the exhaust gas of the Wartsila 4L20 engine. The shell-and-tube heat exchanger is one-shell pass and two-tube passes. The shell side fluid is the exhaust gas assumed as air and the in-tube side fluid is R1234yf, in heat exchanger. The exchanger has square layout with angle of $90^{\circ}$ and $0.2 \mathrm{~m}$ baffle spacing with baffle cut $25 \%$. The diameter of heat tube of the exchanger, which is copper, has $19 \mathrm{~mm}$ at external $(\mathrm{di})$ section and $16 \mathrm{~mm}$ internal $(\mathrm{do})$ section. In the condenser, the sea water is assumed as refrigerant and condenser outlet temperature of the working fluid is considered to be approximately equal to the inlet temperature of sea water. The reason for using R1234yf as the working fluid in the TORC system is that the critical temperature is lower than the exhaust gas temperature value. Thus, the critical threshold can be overcome by a single source. However, the saturation pressure of the working fluid at sea water temperature is higher than water so the turbine outlet pressure is higher than steam (water) turbines the outlet pressure, due to fact that the working fluid is a refrigerant fluid. In this study, the mathematical model of the TORC is written in MATLAB which having useful computing and visualization capabilities for such mathematical models. REFPROP [38] is used to calculate the fluid properties used.

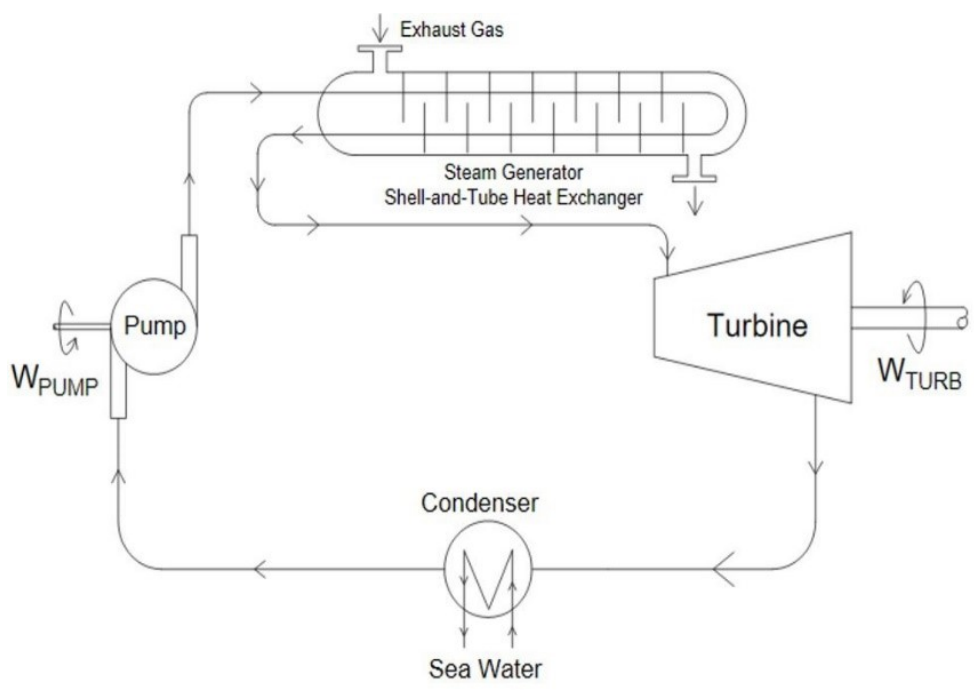

Figure 1. TORC schema

\section{Thermodynamic Modelling}

The formulas used in the thermodynamic analysis are given in below and a T-s diagram of the TORC throughout the cycle is shown in figure 2. Thermodynamic and transport properties are usually called with two intensive properties, i.e., pressure and specific enthalpy. Because using the other intensive properties can result in errors in compressed liquid region and the wet region. The reason for this is that the enthalpy being in the compressed liquid region is changed by the pressure at the constant temperature and the enthalpy being in the wet area is changed by the quality at the constant temperature. 


$$
\begin{gathered}
\dot{W}_{P}=\frac{\dot{m}\left(h_{\text {out }}-h_{\text {in }}\right)}{\eta_{p}} \\
\dot{W}_{T}=\dot{m}\left(h_{\text {in }}-h_{\text {out }}\right) \eta_{t} \\
\dot{W_{n e t}}=\dot{W}_{T}-\dot{W} P \\
\eta_{I}=\frac{\dot{W_{\text {net }}}}{\dot{Q}_{\text {in }}}
\end{gathered}
$$

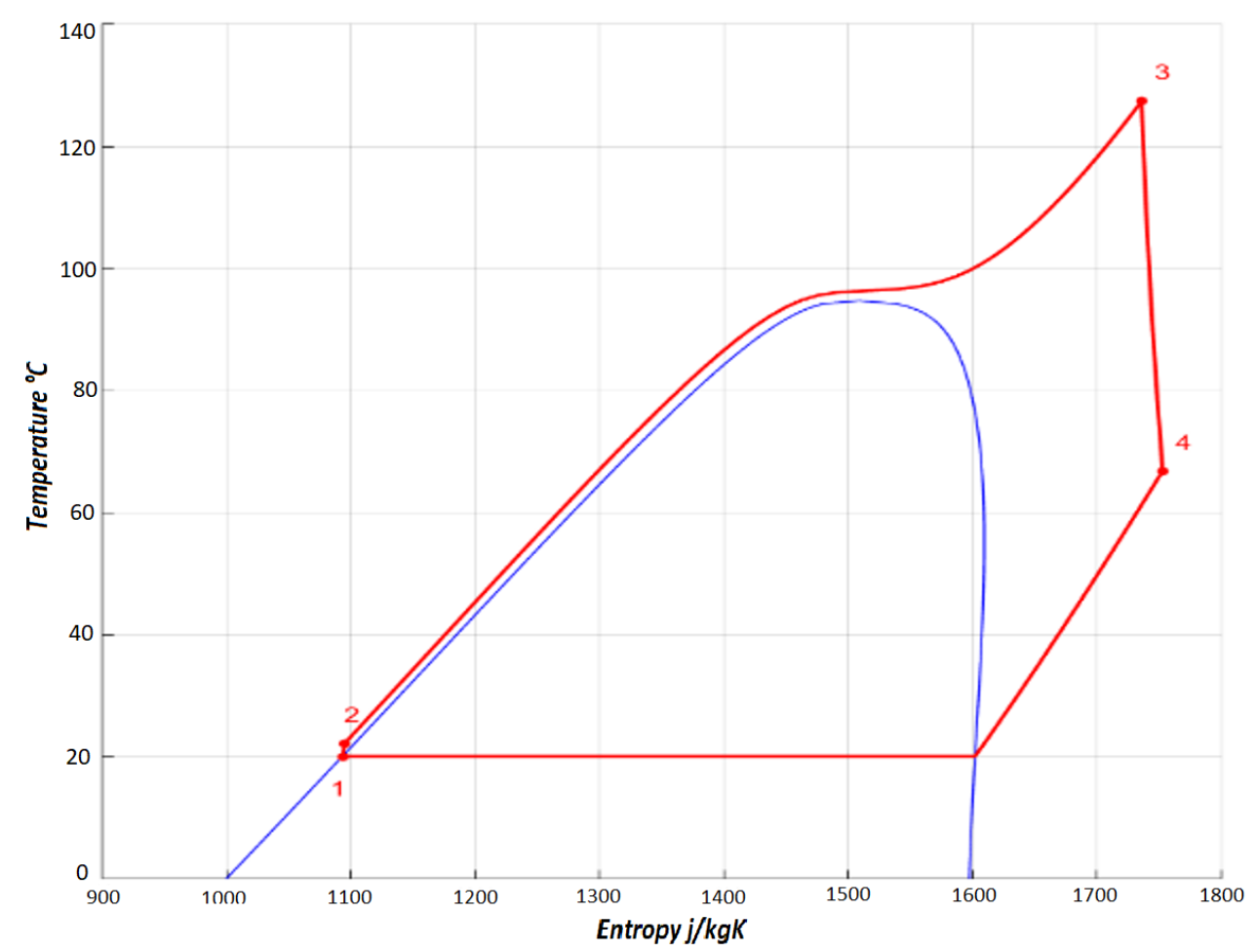

Figure 2. Example $\mathrm{T}-\mathrm{s}$ graph of A TORC

\section{Heat Transfer Modelling}

In this study, one-shell pass and two-tube passes heat exchanger is chosen, as mentioned before. The basic parameters of the heat exchanger are shown following. The convection coefficient of the heat exchanger on the body side is calculated by Kern Method and the other formulas used are shown following. Heat transfer surface area is turned a series to calculate heat transfer surface area is turned a series to calculate the effects of pressure and enthalpy changes on thermodynamic and transport properties. In this way, we make a more accurate calculation in possible dramatic change of properties of fluids. The assumed parameters of the heat exchanger are given below.

Variable parameters of the shell \& tubes heat exchanger;

- Number of the Tubes, Nt: 4-40

- Length of the Tubes, $L: 1-10(\mathrm{~m})$

Constant parameters of the shell \& tubes heat exchanger

- Internal diameter, $d i$, and external diameter, $d o$, are 16 and $19(\mathrm{~mm})$ 
- $\quad$ Baffle Spacing, B: $0.2(\mathrm{~m})$

- $\quad$ Pitch Ratio, Pr: 1.25

- Internal fouling factor, $R f_{i}: 0.0002\left(\mathrm{~m}^{2} \mathrm{~K} / \mathrm{W}\right)$ [39]

- External fouling factor, $R f_{o}: 0.01761\left(\mathrm{~m}^{2} \mathrm{~K} / \mathrm{W}\right)$ [39]

- Tube materiel: Copper

- Equivalent roughness, ep: $0.0015 e-3(\mathrm{~m})$

The tube side Nusselt Number correlations for laminar flow is given in (5) and for turbulence flow is given in (6) [40].

$$
\begin{aligned}
& N u=1,86\left(\frac{\operatorname{RePr} d i}{L}\right)^{1 / 3}\left(\frac{\mu}{\mu_{s}}\right)^{0,14} \\
& N u=\frac{\left(\frac{f}{8}\right)(\operatorname{Re}-1000) \operatorname{Pr}}{1+12,7\left(\frac{f}{8}\right)^{0,5}\left(\operatorname{Pr}^{2 / 3}-1\right)}
\end{aligned}
$$

The tube side pressure lost formulation is defined in (7) [39] and the pressure lost correlations are given in (8-9) for laminar and turbulence flow [40].

$$
\begin{gathered}
\Delta P_{\text {loss }}=\left(\frac{f L N_{P}}{d_{i}}+4 N_{p}\right) \rho u_{m}^{2} \\
f=64 / \operatorname{Re} \\
\frac{1}{\sqrt{f}}=-2 \log \left(\frac{\varepsilon / D}{3,7}+\frac{2,51}{\operatorname{Re} \sqrt{f}}\right)
\end{gathered}
$$

The shell side Nusselt correlation and pressure loss correlation are given in (10 - 11) [39],

$$
\begin{gathered}
N u=0,36\left(\frac{D_{e} G_{s}}{\mu}\right)^{0,55}\left(\frac{C_{p} \mu}{k}\right)^{1 / 3}\left(\frac{\mu_{b}}{\mu_{w}}\right)^{0,14} \\
\Delta P_{\text {loss }}=\frac{f G_{s}\left(N_{b}+1\right) D_{s}}{2 \rho D_{e}\left(\frac{\mu_{w}}{\mu_{b}}\right)^{0,14}}
\end{gathered}
$$

Overall heat transfer coefficient formula is defined in (12) [39],

$$
U_{o}=\left(\frac{d_{o}}{d_{i} h_{\text {in }}}+R_{f i} \frac{d_{o}}{d_{i}}+d_{o} \frac{\ln \left(d_{o} / d_{i}\right)}{2 k}+R_{f o}+\frac{1}{h_{\text {out }}}\right)^{-1}
$$


$\varepsilon-$ NTU method formulations are given in $(13-14)$ [40],

$$
\begin{gathered}
\dot{Q}_{i n}=\varepsilon C_{\min }\left(T_{h i}-T_{c o}\right) \\
N T U=\frac{U_{o} A_{s}}{C_{\min }} \\
\varepsilon=2\left\{1+c+\sqrt{1+c^{2}} \frac{1+\exp \left[-N T U \sqrt{1+c^{2}}\right]}{1-\exp \left[-N T U \sqrt{1+c^{2}}\right]}\right\}^{-1}
\end{gathered}
$$

\section{Preliminary Evaluation of Heat Exchanger}

Number of the tubes and tubes length which are in the shell, effect on working fluid outlet enthalpy will be investigated. Figures 3 and 4 show constant $\mathrm{Nt}$ and L curves respectively. It may be interesting to note that enthalpy value of $N t 12$ is more than enthalpy value of $N t 14$ or the continuous curve is broken in figure 4 at $N t$ 14. The reason for this is that the velocity of flow in the tube decreases with the increase of the total cross sectional area due to the increase of the number of Nt. Moreover, constant Nt and L curves get closer each other upwards and slope of the constant $\mathrm{Nt}$ and L curves approaches zero so it may not be economical to increase the heat transfer area after a certain value.

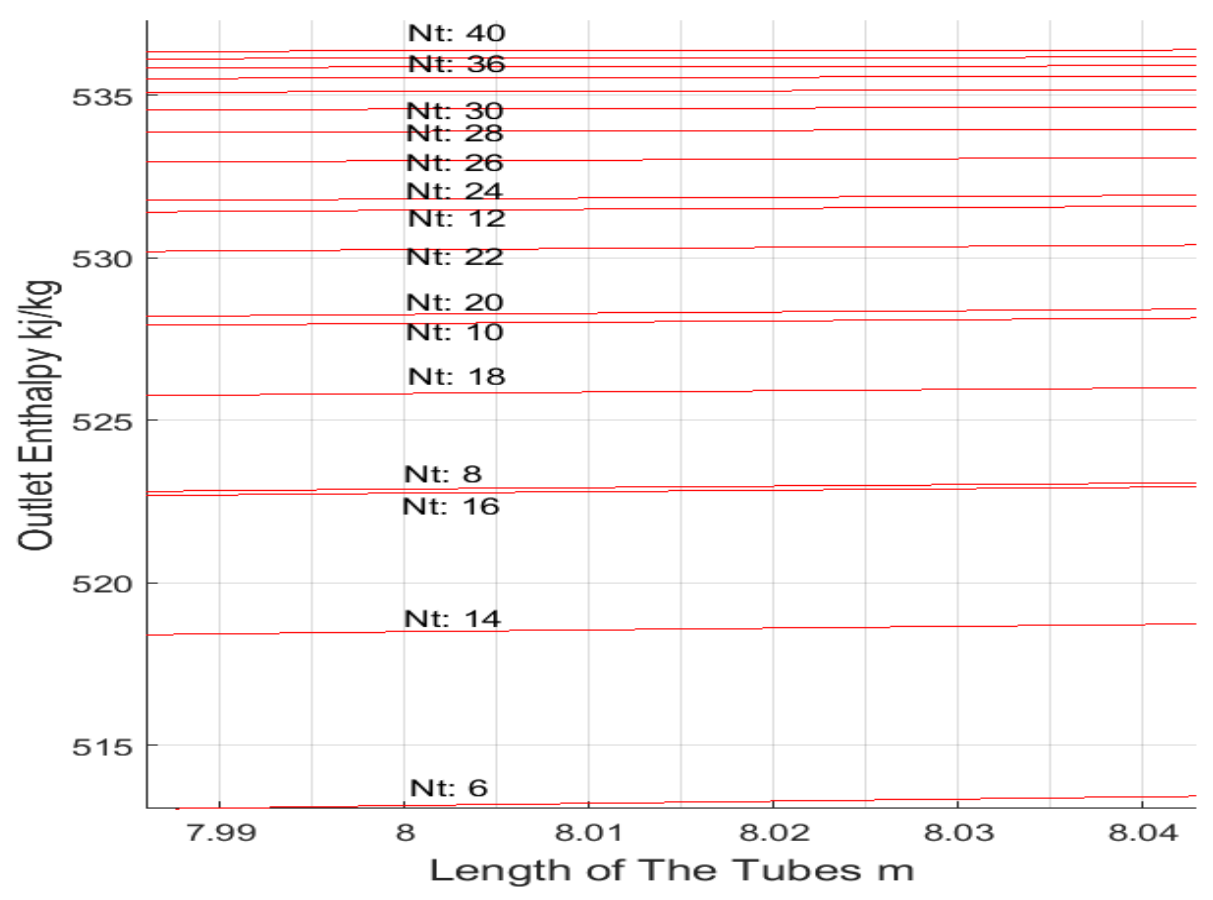

Figure 3. $\mathrm{L}-\mathrm{h}$ graph with constant $\mathrm{Nt}$ 


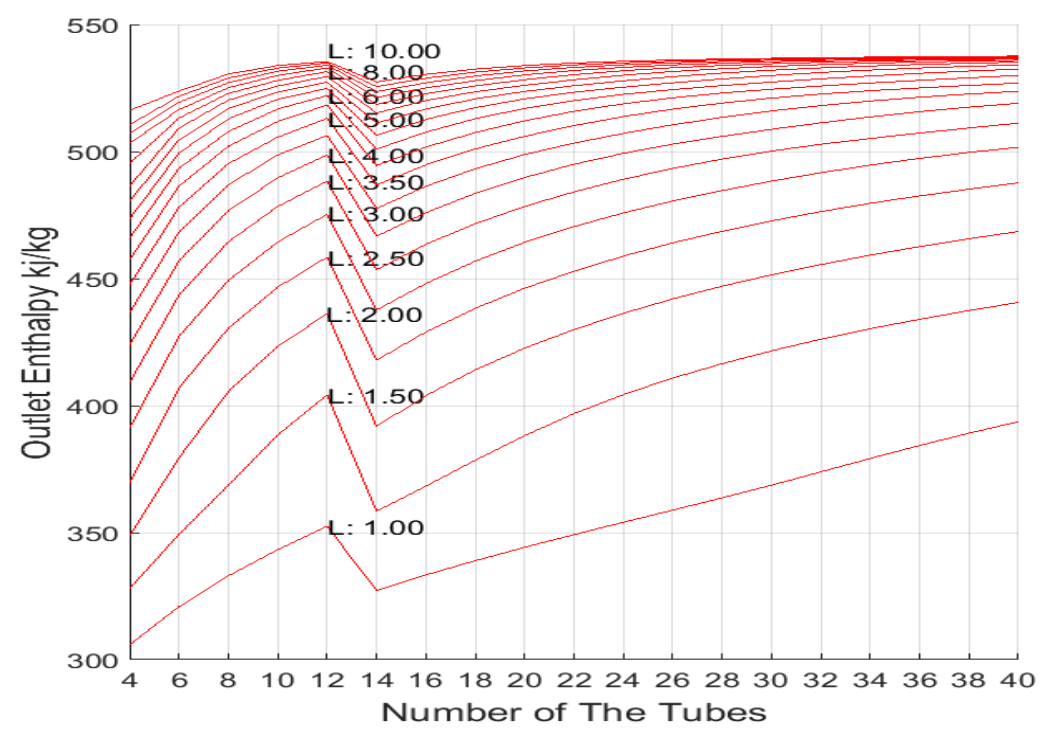

Figure 4. $\mathrm{Nt}-\mathrm{h}$ graph with constant $\mathrm{L}$ curves

Figure 5 shows the effect of the tube length range from $1 \mathrm{~m}$ to $10 \mathrm{~m}$ at a constant $\mathrm{Nt}$ value for 12 on the outlet enthalpy. As shown in Figure 5, as the tube length is increasing, the outlet enthalpy is increasing continuously. Figure 6 shows the effect of the number of the tubes range from 4 to 40 at a constant L value for 8 $m$ on the outlet enthalpy. It is note that a decreasing outlet enthalpy is shown at $\mathrm{Nt}$ value for 14 . The reason for this is as described above. After number of the tubes being 14, as number of the tubes is increasing, the outlet enthalpy is increasing continuously. (Assumed that mass flow of the shell side fluid being exhaust gas $\left(\dot{m}_{e}\right)$ equals to $1.55 \mathrm{~kg} / \mathrm{s}$ and mass flow of the tube side fluid being R1234yf $(\dot{m})$ equals to $1 \mathrm{~kg} / \mathrm{s}$.)

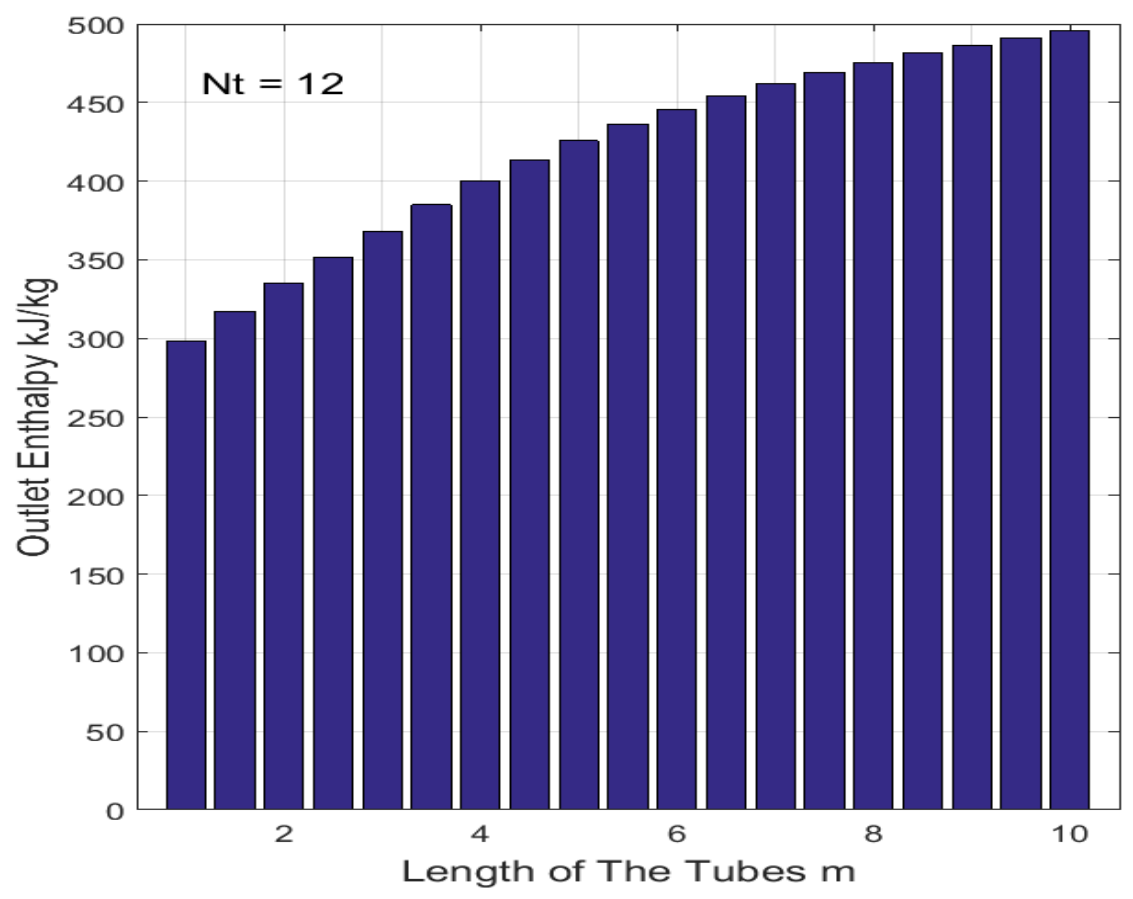

Figure 5. L - h graph with constant L curves Nt: 12 


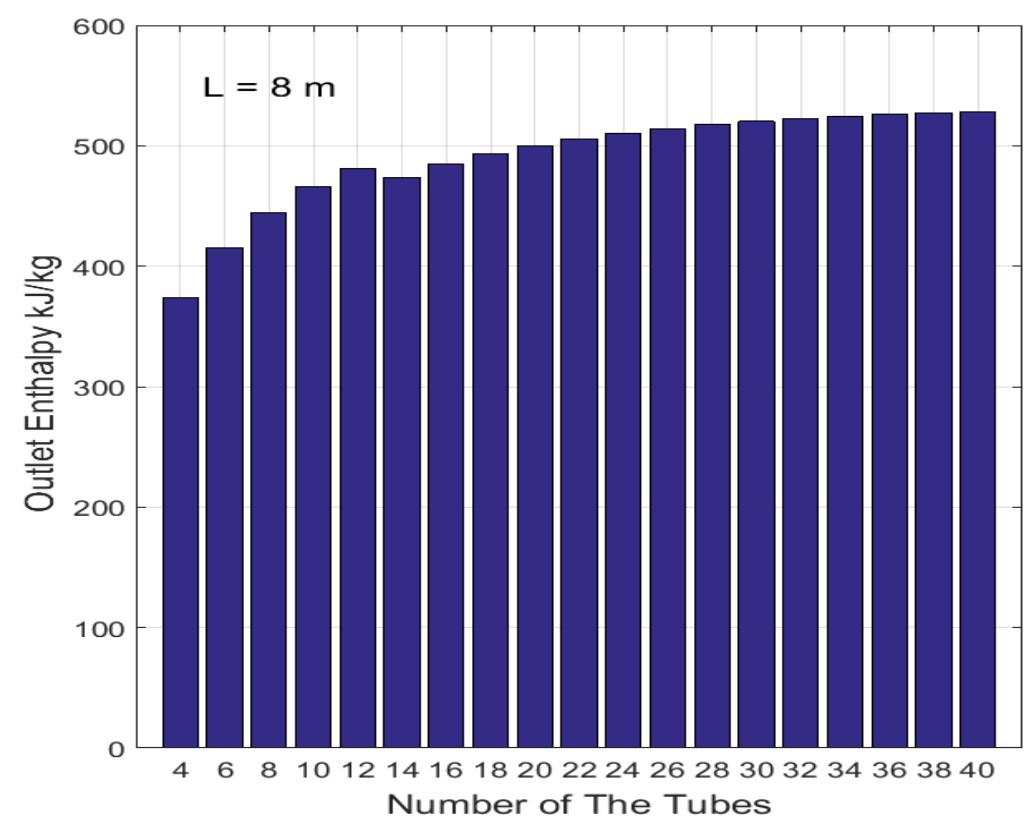

RESULTS AND DISCUSSION

Figure 6. $\mathrm{Nt}$ - h graph with constant $L: 8 \mathrm{~m}$

\section{Parametric Analysis}

Parametric analysis was conducted to investigate effect of the various variables to The Thermal Efficiency and The Net Power of the TORC in the mathematical model for waste heat recovering. Parametric analysis was conducted among themselves pair variables which are exhaust - working fluid mass flow, Nt-L in the heat exchanger. In fact, the exhaust mass flow of selected the ship diesel main engine is constant but the effects of exhaust mass flow to system performance at the same temperature are also shown.

\section{Effect of Nt-L to performance on the TORC}

Figures from 7 to 10 show effect on variations heat transfer area in evaporator to The TORC performance parameters being The Net Power and Efficiency. Figures 7 and 8 are about The Net Power of The TORC while Figures 9 and 10 are about Efficiency of The TORC. Figures 7 and 9 show performance parameters variations with constant $\mathrm{L}$ curves and variable $\mathrm{Nt}$ from 4 to 40 . Figures 8 and 10 show performance parameters variations with constant $\mathrm{Nt}$ curves and variable $\mathrm{L}$ from 1 to $20 \mathrm{~m}$. If figures from 7 to 10 are examined, the curves slope approaches zero after a certain number of tubes and tube length. This means that more tubes and longer tubes will not only improve the performance of the system, but will only increase costs. (Assumed that $\eta c$ and $\eta t$ equal to $0.85, \dot{m}_{e}$ equals to $1.55 \mathrm{~kg} / \mathrm{s}, \dot{m}$ equals to $1 \mathrm{~kg} / \mathrm{s}$, outlet pump pressure equals to $3500 \mathrm{kPa}$ )

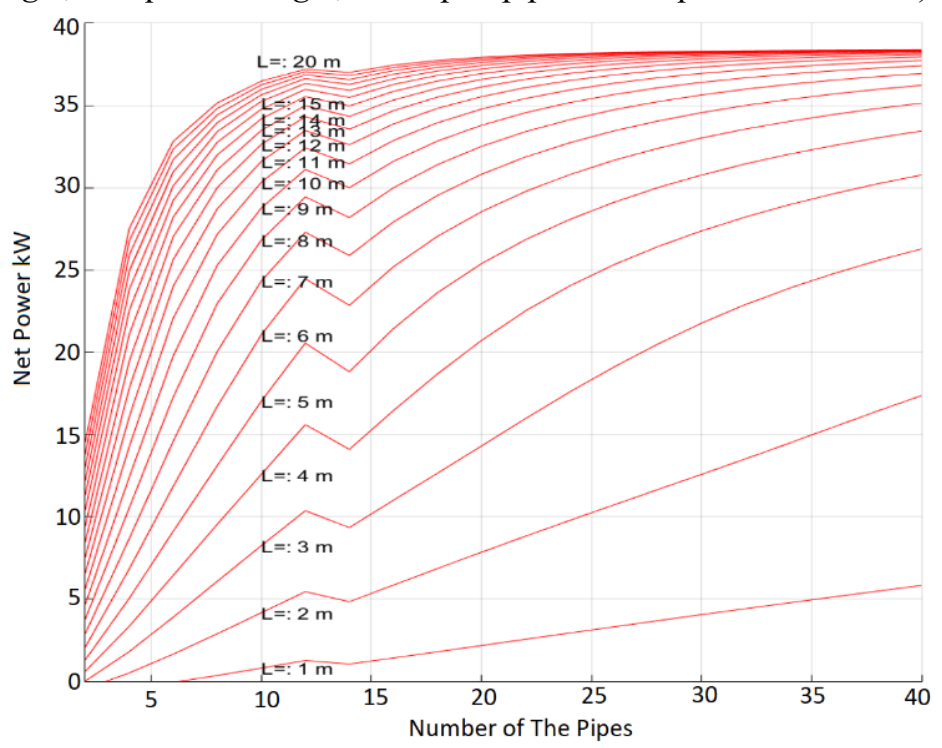

Figure 7. $\mathrm{Nt}-$ Net power graph with constant $\mathrm{L}$ curves 


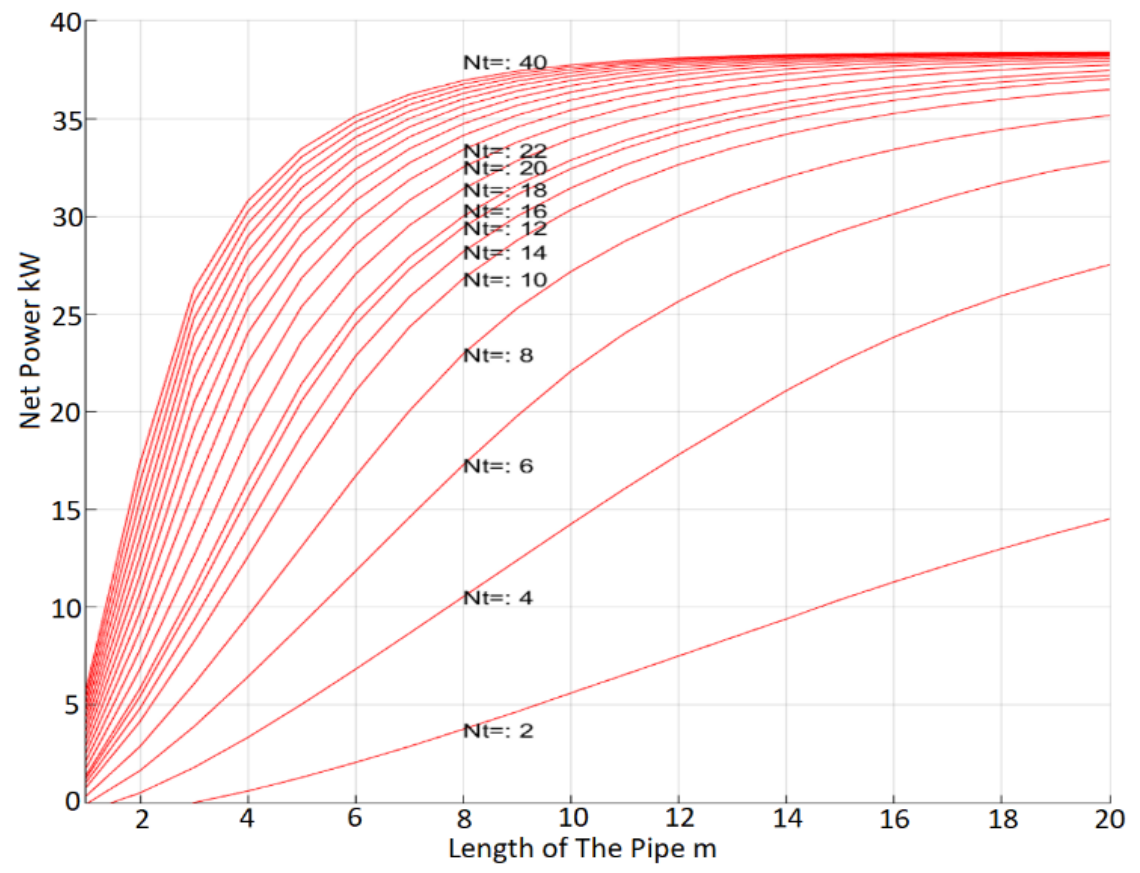

Figure 8. L - Net power graph with constant Nt curves

As shown in Figures 7 and 9, there is a decrease after Nt: 12 value. The reason for this was explained in the above texts. For this reason, if we aim to improve heat transfer by increasing the heat transfer surface area, we must be take consideration to changing the convection coefficient due to decreasing rate of the mass flow.

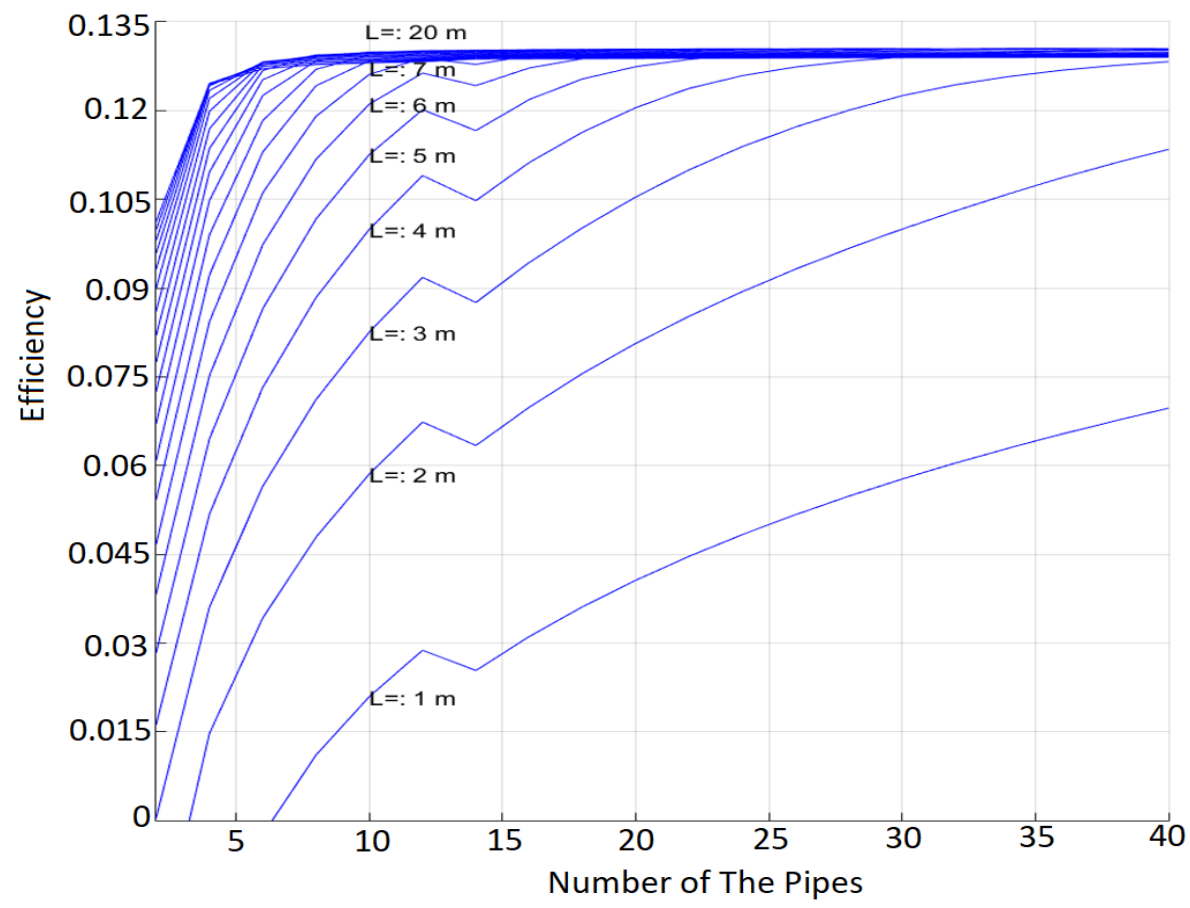

Figure 9. $\mathrm{Nt}$ - Thermal efficiency graph with constant $\mathrm{L}$ curves 


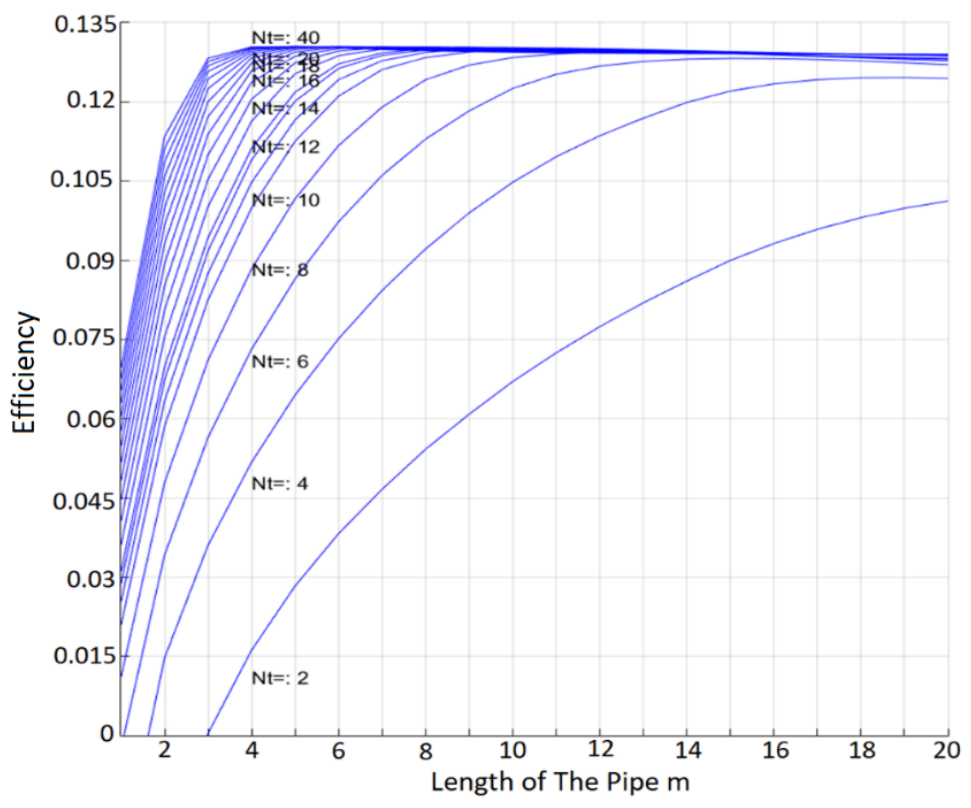

Figure 10. $L-\eta$ with constant $\mathrm{Nt}$ curves

\section{Effect of Working Fluid and Exhaust Fluid Mass Flow Rates on the TORC}

In this section, we examine first the effects of different mass flows of the work fluid to TORC performance at constant exhaust gas mass flow. As can be seen in Figure 11, the maximum power and maximum Efficiency are seen in different mass flows of the working fluid. Figure 12 which is $\mathrm{T}-\mathrm{s}$ graph, shows that the maximum temperature increases as the rate of mass flow decreases. If the Carnot cycle is taken into consideration, it is known that The Thermal Efficiency increases as the maximum temperature increases. However, The Thermal Efficiency of the TORC doesn't increase similar to Carnot cycle even before a certain mass flow value which is $0.6444 \mathrm{~kg} / \mathrm{s}$ The Thermal Efficiency decreases as mass flow decreases even though maximum temperature increases. As working fluid mass flow goes from $0.1 \mathrm{~kg} / \mathrm{s}$ to $0.6444 \mathrm{~kg} / \mathrm{s}$, the increase in Efficiency can be attributed to the increase in total enthalpy. The increase in total enthalpy can be explained by heat transfer phenomenon. As the mass flows increase both convection coefficient and temperature difference increase in the heat exchanger. Thus, the total enthalpy increase by suppressing the decrease in maximum temperature that allows to increase Efficiency. (Assumed that $\eta c$ and $\eta t$ equal to $0.85, \dot{m}_{e}$ equals to $1.55 \mathrm{~kg} / \mathrm{s}, \dot{m}$ equals to 12 , length of the tubes equals to $8 \mathrm{~m}$, outlet pump pressure equals to $3500 \mathrm{kPa}$.)

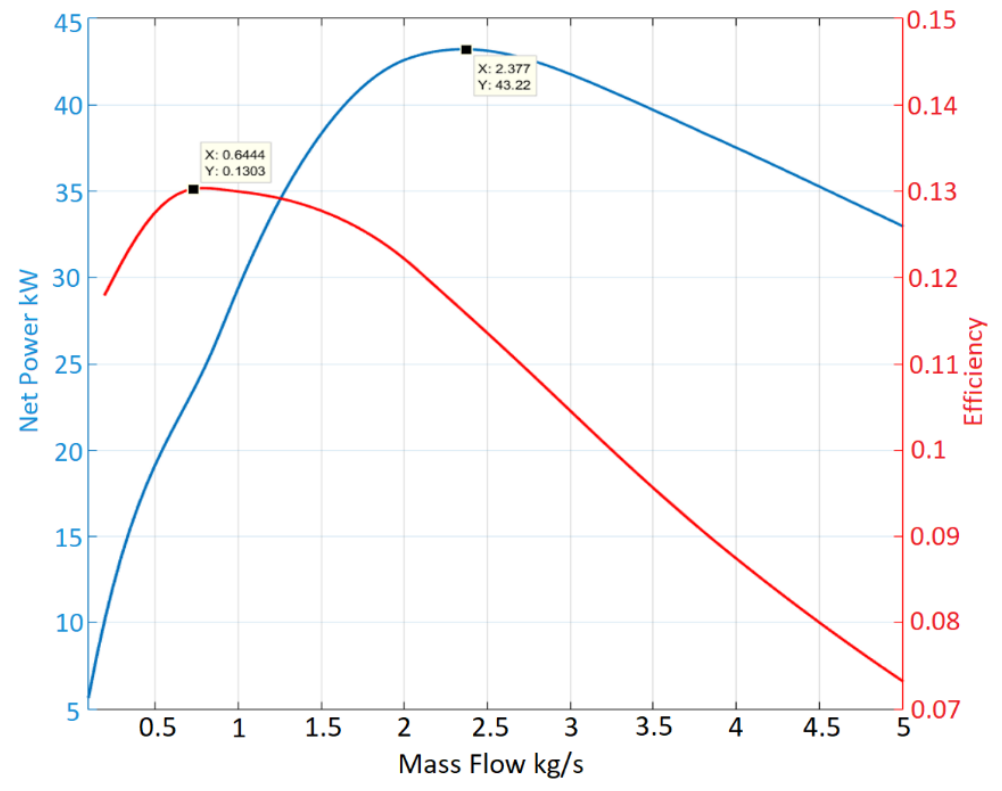

Figure 11. Net power $[\mathrm{kW}]-\eta-\dot{m}$ 


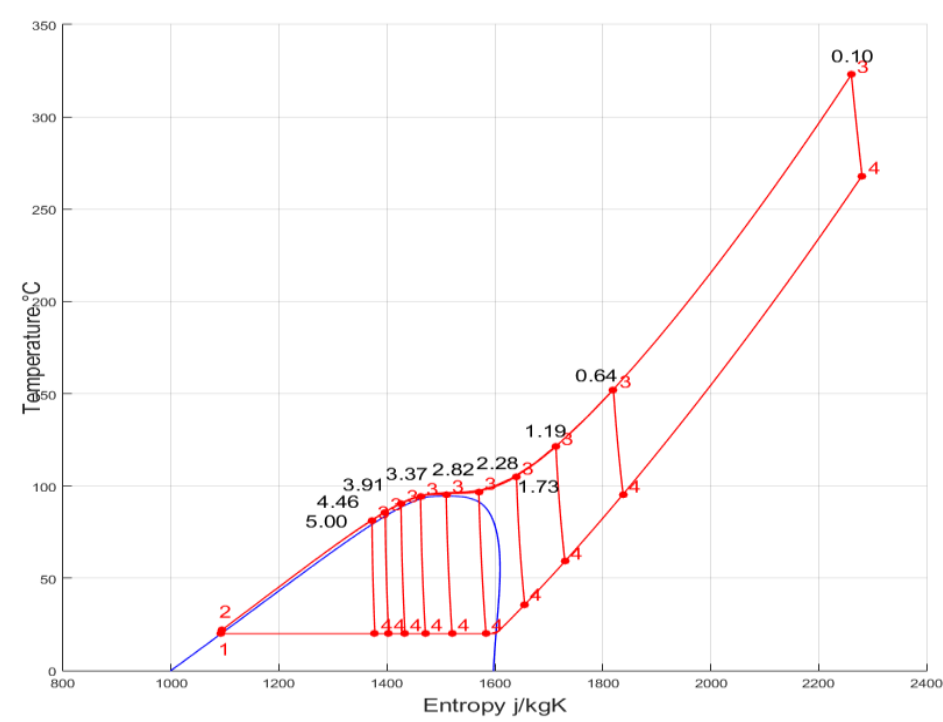

Figure 12. $\mathrm{T}-\mathrm{s}$ with variable working mass flow rate $[\mathrm{kg} / \mathrm{s}]$

The decrease in The Thermal Efficiency may be related to the decrease in the maximum temperature in the mass flows range of $2.377-0.6444 \mathrm{~kg} / \mathrm{s}$ inasmuch as the total increase in total enthalpy can't suppress the decrease in maximum temperature. But for Net Power, the increase in total enthalpy still suppresses the decrease in maximum temperature so The Net Power increases even though The Thermal Efficiency decrease. The decrease in maximum temperature for the after $2.377 \mathrm{~kg} / \mathrm{s}$ of the mass flow suppresses the increase in total enthalpy for The Net Power and a decrease in The Net Power is also seen. Note that the decline slope at the Efficiency is more than the decline slope at The Net Power. The reason why the total increase in enthalpy can't suppress decrease in the maximum temperature can be attributed to the improvement in heat transfer reaching the climax, as mentioned above.

We want to compare different exhaust mass flow with different working fluid mass flow at the same temperature, see Figure 13,14 and 15. Figure 13 show performance parameters in coordinate axes with variable mass flows. Figure 14 and 15 show contour lines The Net Power and Efficiency respectively with variable mass flows. Even though there is a The Net Power increase by increasing exhaust mass flow, the wall of $13 \%$ can't be surpass for The Thermal Efficiency. The reason for the bottleneck in this case is that the maximum temperature of the working fluid can't exceed the exhaust heat inlet temperature. (Assumed that $\eta c$ and $\eta t$ equal to 0.85 , number of the tubes equals to 12 , length of the tubes equals to $8 \mathrm{~m}$, outlet pump pressure equals to $3500 \mathrm{kPa}$.)

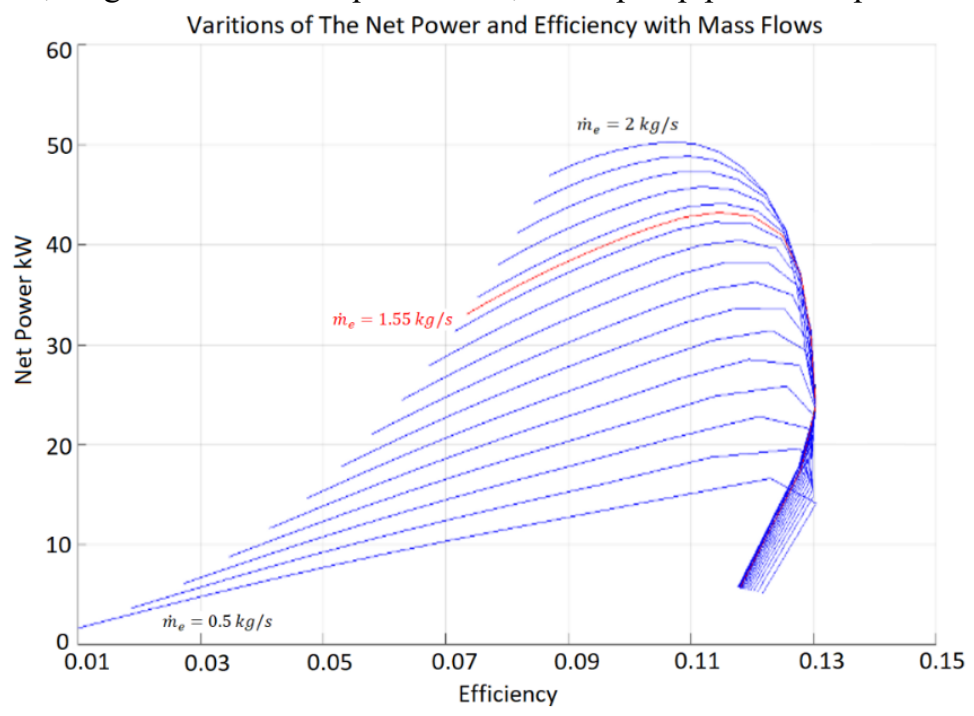

Figure 13. Net power $[\mathrm{kW}]-\eta$ with variable mass flows $[\mathrm{kg} / \mathrm{s}]$ 


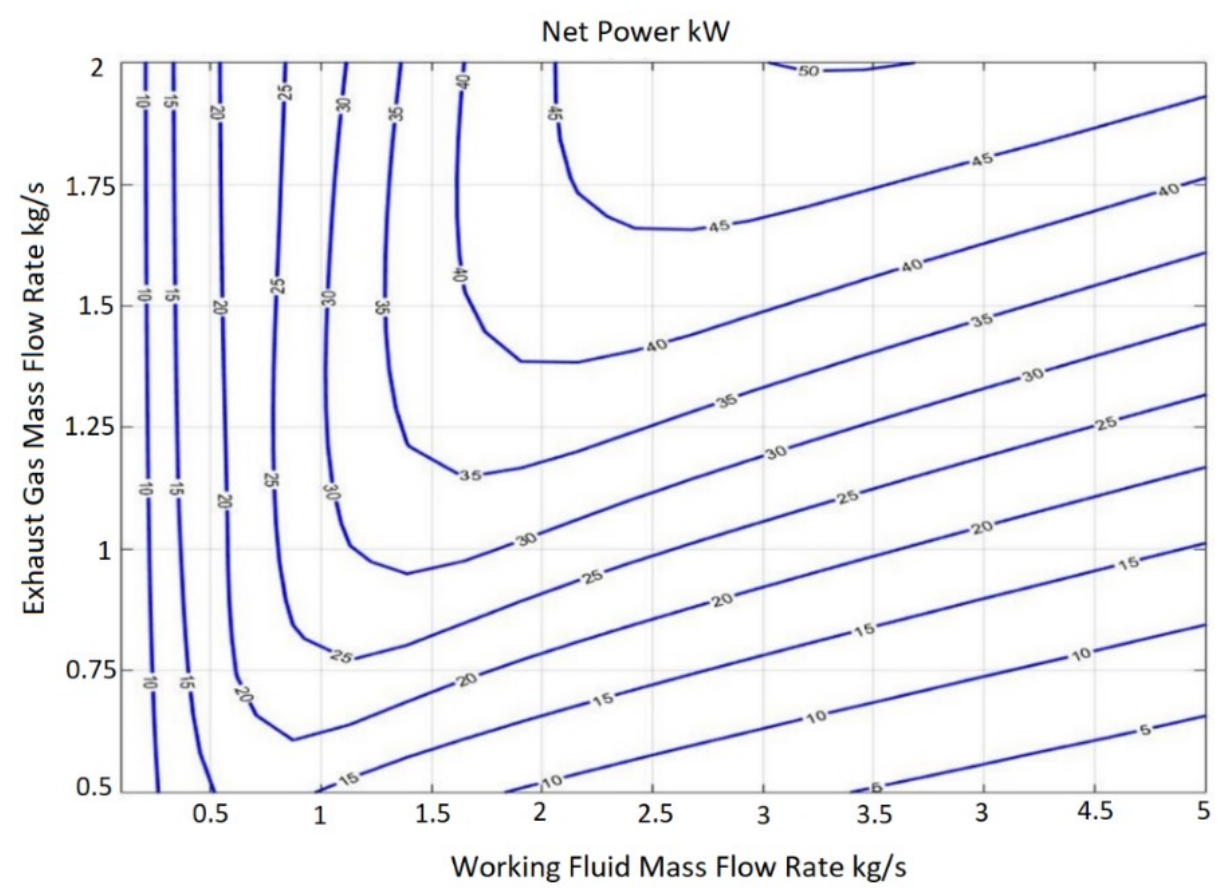

Figure 14. $\dot{m}_{e}-\dot{m}$ - Net power $[\mathrm{kW}]$

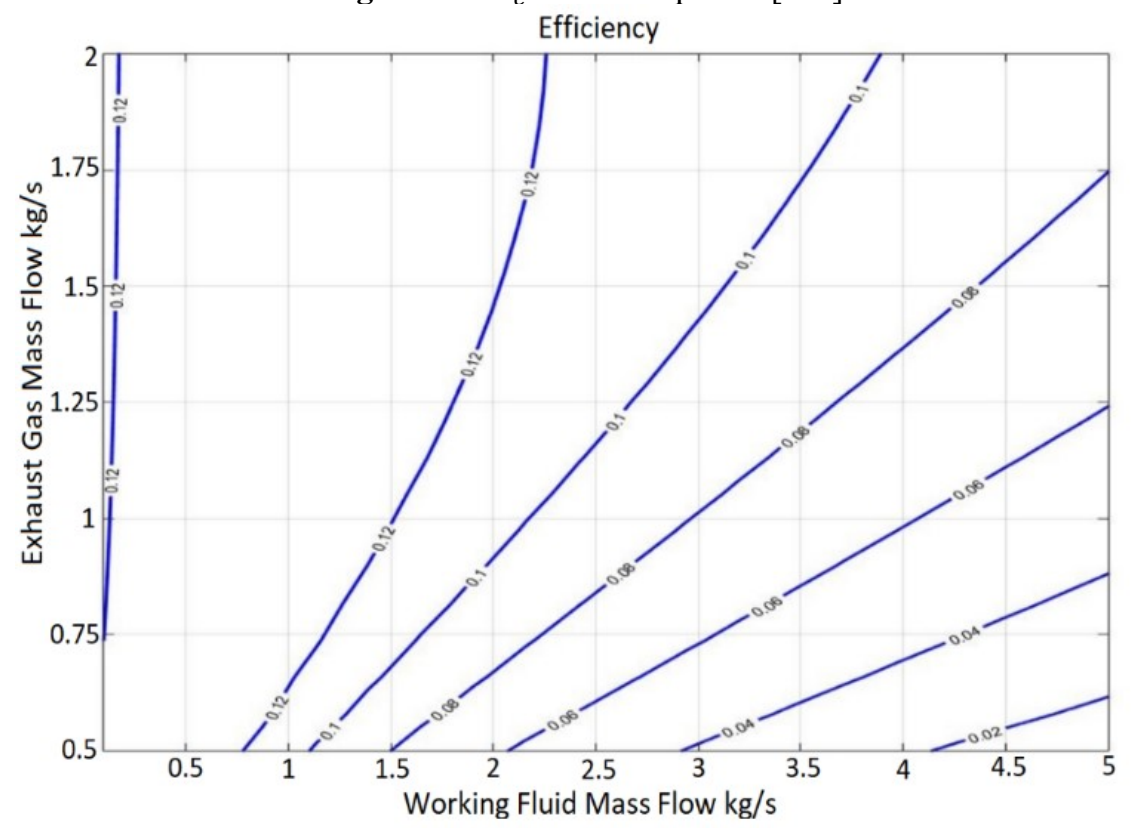

\section{CONCLUSION}

Figure 15. $\dot{m}_{e}-\dot{m}-\eta$

In recent years, the utilization of low temperature waste heat for supplying ORC systems are very popular to develop new energy recovery system technologies and thermal and economic analysis and optimizations of that systems were strongly carried out. In this area, the supercritical fluid applications in the ORC systems are more attractive to convert waste heat to the useful energy. In this study, heat transfer and performance analyses of marine exhaust gases energy used Transcritical Organic Rankine Cycle were done as parametrically. In this study, the results show that;

- Increasing of length of the tube is more effective than increasing of number of the tube for increasing system performance.

- As heat transfer area increases after a certain value, rate of increase of the system performance parameters decrease. 
- Important system performance parameter for waste heat recovery is The Net Power. Levelized Energy Cost (LEC) could be using instead of The Thermal Efficiency for making an economic decision.

- In most case, The Thermal Efficiency is below $13 \%$. Because, thermal quality of the exhaust gases medium quality [41].

- In most case, The Net Power is range from 3\%-7\% of total main engine output. With other waste heat sources and Efficiency enhancing measures, The Net Power is range from $10 \%-12 \%$ of total main engine output [42].

- The rate of increasing in The Net Power is faster the rate of increasing in The Thermal Efficiency with increasing exhaust gas mass flow rate. The reason for this is increase in the quantity of the exhaust gas not quality of the exhaust gas.

- Increasing exhaust gas mass flow rate, optimum working mass flow rate is increasing for The Net Power. The reason for this is Heat transfer is improved by Pinch point having avoided.

- The turbine outlet pressure is mostly dependent on the temperature of the refrigerant in the condenser. So, by adding a regenerator, the expansion at turbine is improved slightly and The Thermal Efficiency is increased also [43].

In order to make a realistic approach; the economic evaluation, environmental effects and second law analyses of TORC system will be studied for future work.

\section{ACKNOWLEDGEMENT}

This paper was compiled from presented master thesis by Kaya [43] at Graduate School of Natural and Applied Sciences of Yildiz Technical University.

\section{NOMENCLATURE}

$\dot{m} \quad$ Working fluid flow rate $(\mathrm{kg} / \mathrm{s})$

$\dot{m}_{e} \quad$ Exhaust fluid flow rate $(\mathrm{kg} / \mathrm{s})$

$\eta \quad$ Thermal efficiency

$\eta_{T} \quad$ Turbine isentropic efficiency

$\eta_{P} \quad$ Pump isentropic efficiency

$T \quad$ Temperature (K)

$P \quad$ Pressure $(\mathrm{kPa})$

$h \quad$ Specific enthalpy $(\mathrm{kJ} / \mathrm{kg})$

$s \quad$ Specific entropy $(\mathrm{kJ} / \mathrm{kgK})$

$U \quad$ Overall heat transfer coefficient $\left(\mathrm{W} / \mathrm{m}^{2} \mathrm{~K}\right)$

$\dot{Q} \quad$ Transferred thermal energy (W)

$\dot{W} \quad$ Power $(\mathrm{W})$

$\mathrm{Nu} \quad$ Nusselt number

Pr Prandtl number

NTU Number of transfer units

Gs Mass velocity $\left(\mathrm{kg} / \mathrm{m}^{2} \mathrm{~s}\right)$

di Internal diameter (m)

do External diameter (m)

TORC Transcritical Organic Rankine Cycle

$\mu \quad$ Dynamic viscosity $(\mathrm{kg} . \mathrm{m} / \mathrm{s})$

$\mathrm{De} \quad$ Equivalent diameter (m)

$C p \quad$ Constant pressure specific heat $(\mathrm{J} / \mathrm{kgK})$

Cmin Minimum heat capacity (W/K)

$\rho \quad$ Density $\left(\mathrm{kg} / \mathrm{m}^{3}\right)$

$N_{P} \quad$ Number of the tube passes

$u_{m} \quad$ Overall velocity inside tubes $(\mathrm{m} / \mathrm{s})$

$h_{\text {in }} \quad$ Internal transport coefficient $\left(\mathrm{W} / \mathrm{m}^{2} \mathrm{~K}\right)$

$h_{\text {out }}$ External transport coefficient $\left(\mathrm{W} / \mathrm{m}^{2} \mathrm{~K}\right)$

$\varepsilon \quad$ Effectiveness coefficient 


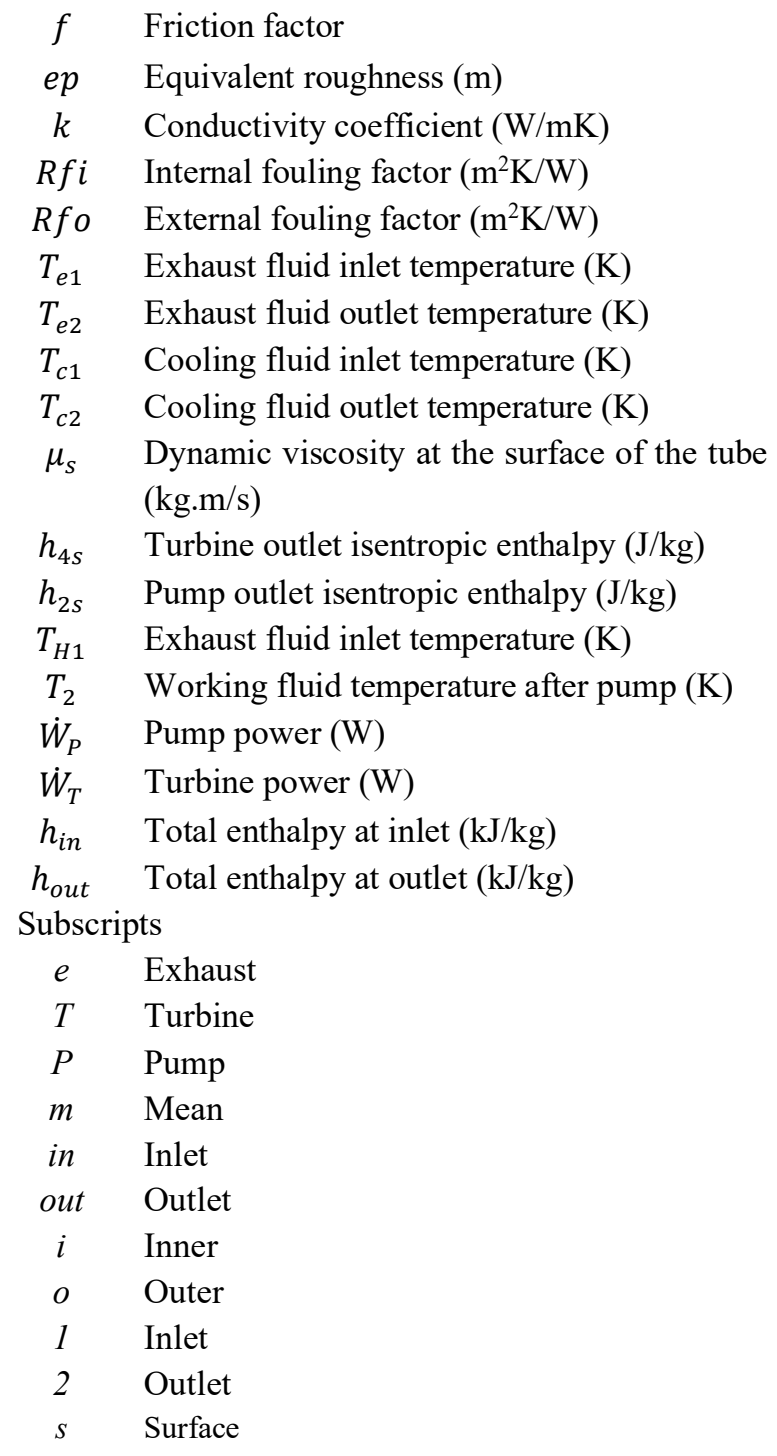

\section{REFERENCES}

[1] Srinivasan KK, Mago PJ, Krishnan SR. Analysis of exhaust waste heat recovery from a dual fuel low temperature combustion engine using an Organic Rankine Cycle. Energy 2010;35:2387-99. https://doi.org/10.1016/j.energy.2010.02.018.

[2] Katsanos CO, Hountalas DT, Pariotis EG. Thermodynamic analysis of a Rankine cycle applied on a diesel truck engine using steam and organic medium. Energy Convers Manag 2012;60:68-76. https://doi.org/10.1016/j.enconman.2011.12.026.

[3] Hossain SN, Bari S. Waste heat recovery from the exhaust of a diesel generator using Rankine Cycle. Energy Convers Manag 2013;75:141-51. https://doi.org/10.1016/j.enconman.2013.06.009.

[4] Domingues A, Santos H, Costa M. Analysis of vehicle exhaust waste heat recovery potential using a Rankine cycle. Energy 2013;49:71-85. https://doi.org/10.1016/j.energy.2012.11.001.

[5] Yu G, Shu G, Tian H, Wei H, Liu L. Simulation and thermodynamic analysis of a bottoming Organic Rankine Cycle (ORC) of diesel engine (DE). Energy 2013;51:281-90. https://doi.org/10.1016/j.energy.2012.10.054.

[6] Zhu S, Deng K, Qu S. Energy and exergy analyses of a bottoming Rankine cycle for engine exhaust heat recovery. Energy 2013;58:448-57. https://doi.org/10.1016/j.energy.2013.06.031.

[7] Song J, Li Y, Gu C, Zhang L. Thermodynamic analysis and performance optimization of an ORC (Organic Rankine Cycle) system for multi-strand waste heat sources in petroleum refining industry. Energy 2014;71:673-80. https://doi.org/10.1016/j.energy.2014.05.014.

[8] Wiedemann J, Span R. Simulation of an Exhaust Heat Driven Rankine-Cycle for Mobile Applications. Energy Procedia 2014;61:2658-61. https://doi.org/10.1016/j.egypro.2014.12.269. 
[9] Zhang Y-Q, Wu Y-T, Xia G-D, Ma C-F, Ji W-N, Liu S-W, et al. Development and experimental study on organic Rankine cycle system with single-screw expander for waste heat recovery from exhaust of diesel engine. Energy 2014;77:499-508. https://doi.org/10.1016/j.energy.2014.09.034.

[10] Allouache A, Leggett S, Hall MJ, Tu M, Baker C, Fateh H. Simulation of Organic Rankine Cycle Power Generation with Exhaust Heat Recovery from a 15 liter Diesel Engine. SAE Int J Mater Manuf 2015;8:22738. https://doi.org/10.4271/2015-01-0339.

[11] Amicabile S, Lee J-I, Kum D. A comprehensive design methodology of organic Rankine cycles for the waste heat recovery of automotive heavy-duty diesel engines. Appl Therm Eng 2015;87:574-85. https://doi.org/10.1016/j.applthermaleng.2015.04.034.

[12] Bei C, Zhang H, Yang F, Song S, Wang E, Liu H, et al. Performance Analysis of an Evaporator for a Diesel Engine-Organic Rankine Cycle (ORC) Combined System and Influence of Pressure Drop on the Diesel Engine Operating Characteristics. Energies 2015;8:5488-515. https://doi.org/10.3390/en8065488.

[13] Di Battista D, Mauriello M, Cipollone R. Waste heat recovery of an ORC-based power unit in a turbocharged diesel engine propelling a light duty vehicle. Appl Energy 2015;152:109-20. https://doi.org/10.1016/j.apenergy.2015.04.088.

[14] Guo C, Du X, Yang L, Yang Y. Organic Rankine cycle for power recovery of exhaust flue gas. Appl Therm Eng 2015;75:135-44. https://doi.org/10.1016/j.applthermaleng.2014.09.080.

[15] Muhammad U, Imran M, Lee DH, Park BS. Design and experimental investigation of a $1 \mathrm{~kW}$ organic Rankine cycle system using R245fa as working fluid for low-grade waste heat recovery from steam. Energy Convers Manag 2015;103:1089-100. https://doi.org/10.1016/j.enconman.2015.07.045.

[16] Peris B, Navarro-Esbrí J, Molés F, Mota-Babiloni A. Experimental study of an ORC (organic Rankine cycle) for low grade waste heat recovery in a ceramic industry. Energy 2015;85:534-42. https://doi.org/10.1016/j.energy.2015.03.065.

[17] Wang T, Zhang Y, Peng Z, Shu G. Benefits and Cost-effectiveness Analysis of Exhaust Energy Recovery System Using Low and High Boiling Temperature Working Fluids in Rankine Cycle. Energy Procedia 2015;66:53-6. https://doi.org/10.1016/j.egypro.2015.02.028.

[18] Lemmens S, Lecompte S. Case study of an organic Rankine cycle applied for excess heat recovery: Technical, economic and policy matters. Energy Convers Manag 2017;138:670-85. https://doi.org/10.1016/j.enconman.2017.01.074.

[19] Yang M-H, Yeh R-H. Analyzing the optimization of an organic Rankine cycle system for recovering waste heat from a large marine engine containing a cooling water system. Energy Convers Manag 2014;88:9991010. https://doi.org/10.1016/j.enconman.2014.09.044.

[20] Yang M-H, Yeh R-H. Thermodynamic and economic performances optimization of an organic Rankine cycle system utilizing exhaust gas of a large marine diesel engine. Appl Energy 2015;149:1-12. https://doi.org/10.1016/j.apenergy.2015.03.083.

[21] Yang M-H. Thermal and economic analyses of a compact waste heat recovering system for the marine diesel engine using transcritical Rankine cycle. Energy Convers Manag 2015;106:1082-96. https://doi.org/10.1016/j.enconman.2015.10.050.

[22] Yang M-H, Yeh R-H. Thermo-economic optimization of an organic Rankine cycle system for large marine diesel engine waste heat recovery. Energy 2015;82:256-68. https://doi.org/10.1016/j.energy.2015.01.036.

[23] Yun E, Park H, Yoon SY, Kim KC. Dual parallel organic Rankine cycle (ORC) system for high efficiency waste heat recovery in marine application. J Mech Sci Technol 2015;29:2509-15. https://doi.org/10.1007/s12206-015-0548-5.

[24] Yang M-H. Optimizations of the waste heat recovery system for a large marine diesel engine based on transcritical Rankine cycle. Energy 2016;113:1109-24. https://doi.org/10.1016/j.energy.2016.07.152.

[25] Zabek D, Penton J, Reay D. Optimization of waste heat utilization in oil field development employing a transcritical Organic Rankine Cycle (ORC) for electricity generation. Appl Therm Eng 2013;59:363-9. https://doi.org/10.1016/j.applthermaleng.2013.06.001.

[26] Landelle A, Tauveron N, Revellin R, Haberschill P, Colasson S. Experimental Investigation of a Transcritical Organic Rankine Cycle with Scroll Expander for Low-Temperature Waste Heat Recovery. Energy Procedia 2017;129:810-7. https://doi.org/10.1016/j.egypro.2017.09.142.

[27] Kosmadakis G, Manolakos D, Papadakis G. Experimental investigation of a low-temperature organic Rankine cycle (ORC) engine under variable heat input operating at both subcritical and supercritical conditions. Appl Therm Eng 2016;92:1-7. https://doi.org/10.1016/j.applthermaleng.2015.09.082.

[28] Desideri A, Gusev S, van den Broek M, Lemort V, Quoilin S. Experimental comparison of organic fluids for low temperature ORC (organic Rankine cycle) systems for waste heat recovery applications. Energy 2016;97:460-9. https://doi.org/10.1016/j.energy.2015.12.012.

[29] Hsieh J-C, Fu B-R, Wang T-W, Cheng Y, Lee Y-R, Chang J-C. Design and preliminary results of a 20-kW transcritical organic Rankine cycle with a screw expander for low-grade waste heat recovery. Appl Therm Eng 2017;110:1120-7. https://doi.org/10.1016/j.applthermaleng.2016.09.047. 
[30] Oyewunmi OA, Ferré-Serres S, Lecompte S, van den Broek M, De Paepe M, Markides CN. An Assessment of Subcritical and Trans-critical Organic Rankine Cycles for Waste-heat Recovery. Energy Procedia 2017;105:1870-6. https://doi.org/10.1016/j.egypro.2017.03.548.

[31] Tian R, An Q, Zhai H, Shi L. Performance analyses of transcritical organic Rankine cycles with large variations of the thermophysical properties in the pseudocritical region. Appl Therm Eng 2016;101:183-90. https://doi.org/10.1016/j.applthermaleng.2016.02.126.

[32] Zhu J, Bo H, Li T, Hu K, Liu K. A thermodynamics comparison of subcritical and transcritical organic Rankine cycle system for power generation. J Cent South Univ 2015;22:3641-9. https://doi.org/10.1007/s11771-015-2905-z.

[33] Dong J, Zhang X, Wang J. Experimental investigation on heat transfer characteristics of plat heat exchanger applied in organic Rankine cycle (ORC). Appl Therm Eng 2017;112:1137-52. https://doi.org/10.1016/j.applthermaleng.2016.10.190.

[34] Wang Y, Shen S, Yuan D. Frictional pressure drop during steam stratified condensation flow in vacuum horizontal tube. Int $\mathrm{J}$ Heat Mass Transf 2017;115:979-90. https://doi.org/10.1016/j.ijheatmasstransfer.2017.08.088.

[35] Karellas S, Schuster A, Leontaritis A-D. Influence of supercritical ORC parameters on plate heat exchanger design. Appl Therm Eng 2012;33-34:70-6. https://doi.org/10.1016/j.applthermaleng.2011.09.013.

[36] Nielsen OJ, Javadi MS, Sulbaek Andersen MP, Hurley MD, Wallington TJ, Singh R. Atmospheric chemistry of CF3CFCH2: Kinetics and mechanisms of gas-phase reactions with $\mathrm{Cl}$ atoms, $\mathrm{OH}$ radicals, and $\mathrm{O} 3$. Chem Phys Lett 2007;439:18-22. https://doi.org/10.1016/j.cplett.2007.03.053.

[37] Wärtsilä 20 - Diesel engine n.d. https:/www.wartsila.com/products/marine-oil-gas/engines-generatingsets/diesel-engines/wartsila-20 (accessed August 14, 2017).

[38] Johnson SG. REFPROP. NIST 2013. https://www.nist.gov/refprop.

[39] Kakaç S, Liu H, Pramuanjaroenkij A. Heat Exchangers: Selection, Rating, and Thermal Design. CRC Press; 2012.

[40] Cengel YA, Ghajar AJ. Heat and Mass Transfer: A Practical Approach. 2nd ed. McGraw-Hill Education; 2014.

[41] Waste Heat Recovery: - Technology and Opportunities in U.S. Industry. U.S. Department of Energy; 2008.

[42] Waste Heat Recovery System (WHRS) for Reduction of Fuel Consumption, Emission and EEDI. Denmark: MAN Diesel \& Turbo; 2012.

[43] Kaya I. Waste heat recovery with transcritical organic Rankine cycle at vessels. Master Thesis. Yildiz Technical University, 2017. 